\title{
TINGKAT PEMBERIAN SEKAM PADI DENGAN MONO SODIUM GLUTAMAT DISUPLEMENTASI EFFECTIVE MICROORGANISMS-4 TERHADAP KARKAS DAN KUALITAS DAGING ITIK CAMPBELL
}

\author{
YADNYA, T. G. B., I M. NURIYASA, N. M. S. SUKMAWATI, DAN A. A. A. S. TRISNADEWI \\ Fakultas Peternakan, Universitas Udayana \\ e-mail: belawayadnya_fapet@yahoo.com
}

\begin{abstract}
ABSTRAK
Penelitian bertujuan untuk mengatahui pemberian ransum dengan sumber serat yang berbeda dengan Monosodium Glutamat disuplementasi Effective Microorganisms-4 (EM-4) terhadap karkas dan kualitas daging itik Campbell. Penelitian menggunakan rancangan acak lengkap (RAL), dengan empat perlakuan yaitu pemberian ransum kontrol (A), ransum dengan 4,54\% sekam padi, 3,36\% MSG, dan EM-4 (B), Ransum dengan 5,97\% sekam padi, 5,94\% MSG, dan EM-4 (C), dan ransum dengan 6,94\% sekam padi, 6,36\% MSG dan EM-4 (D). Setiap perlakuan dengan empat ulangan, dan setiap ulangan berisi empat ekor itik Campbell. Variabel yang diamati adalah bobot karkas, persentase karkas dan kualitas daging termasuk kadar air, daya ikat air, dan pH. Hasil penelitian menunjukkan bahwa pemberian perlakuan B dan C bobot potong masing-masing adalah 18,18\% dan 10,38\% berpengaruh nyata, sedangkan dengan perlakuan $\mathrm{D}$ tidak berpengaruh terhadap bobot karkas dibandingkan dengan perlakuan A. Pemberian perlakuan B, C, dan D tidak berpengaruh terhadap persentase karkas. Pemberian perlakuan B, C, dan D dapat meningkatkan persentase daging dan tulang, sedangkan pada persentase lemak karkas terjadi penurunan secara nyata daripada perlakuan A. Penilaian kualitas daging secara obyektif, pada pemberian perlakuan B, C, dan D tidak berpengaruh terhadap pH dan kadar air daging, sedangkan pada daya ikat air terjadi peningkatan berbeda nyata dibandingkan dengan pemberian perlakuan A. Penilaian kualitas daging secara organoleptik, pada pemberian perlakuan B, C dan D dapat meningkatkan secara nyata aroma, cita rasa dan tekstur, kecuali pada perlakuan C dan D tidak berpengaruh terhadap cita rasa daripada pemberian perlakuan A. Dari hasil penelitian dapat disimpulkan bahwa pemberian ransum dengan 4,94\% sekam padi dan 3,36\% MSG dan EM-4 (perlakuan B) menghasilkan karkas dan kualitas daging yang terbaik diantara perlakuan.
\end{abstract}

Kata kunci :sekam padi, mono sodium glutamat, effective microorganisms-4 (EM-4), karkas dan kualitas daging, itik campbell

\section{STUDY OF OFFERING DIETS CONTAINING RICE HULL, MONOSODIUM GLUTAMAT SUPPLEMENTED WITH EFFECTIVE MICROORGANISMS-4 (EM-4) OF THE CARCASS AND MEAT QUALITY OF THE CAMPBELL DUCKS}

\begin{abstract}
The experiment was carried out to study of offering diets containing rice hull , monosodium glutamat (MSG) supplemented with effecctive microorganisms-4 (EM-4) of the carcass and meat quality on the campbell ducks. A completely randomized design with four treatments such as diet without rice hull, MSG and EM-4 (A), diets with 4.54\% rice hull, 3.36\% MSG and EM-4 (B), diets with 5.97\% rice hull, 5.95\% MSG (C)., diets with 6.94\% rice hull, 6.36\% MSG, and EM-4 (D). Each treatment with four replications and consists of four female ducks. The variables observed were were slaughter weight, carcass weight, carcass percentage, carcass physical composition (meat percentage, bone, and fat). Meat quality were $\mathrm{pH}$, water concentration, and water holding capacity. It showed that diet feed consumption of ducks fed B and C treatment found could increase of slaughter weight were $18.18 \%$ and $10.38 \%$ sinificant different and treatment D was not affected the slaughter weight compared with treatment A. Offering treatment B and C could increase carcass weight significantly, but treatment D not affected carcass weight compared with control treatment. Offering treatment B, C, and D were not affected the carcass percentge compared with treatment A. Carcass physical composition of campbell ducks on treatment B, C, and D could increase meat and bone percentage and could decrease fat percentagesignificantly compared with treatment $\mathrm{A}$. The evalution with objective meat quality method, with offering fed diets treatment $\mathrm{B}, \mathrm{C}$, and $\mathrm{D}$ not affected $\mathrm{pH}$ and
\end{abstract}


water concentration, but on water holding capacity could increase significantly different compared with control treatment. The evaluation with organoleptic meat quality method on treatment B, C, and D could increase of odor and texture score, but on .treatment $\mathrm{C}$ and $\mathrm{D}$ not affected meat taste score compared with treatment $\mathrm{A}$. It can be concluded that ducks fed diets containing rice hull 4.94\%, 3.36\% and EM-4 can improve carcass and meat quality of the campbell duck.

Key word : rice hull, mono sodium glutamat, effective microorganisms-4 (EM-4), carcass and meat quality, campbell duck

\section{PENDAHULUAN}

Pemanfaatan limbah pertanian atau agropertanian sangat baik untuk penyediaan pakan berkelanjutan. Disamping dapat menekan biaya pakan dan ketersediaannya berkelanjutan, tidak bersaing dengan kebutuhan manusia karena limbah tersebut dapat digunakan untuk bahan pakan ternak alternatif sebagai pengganti sumber energi atau protein maupun sebagai sumber mikronutrien karena produk tersebut kaya akan zat - zat nutrisi (Pilliang, 1997). Hal ini dapat dilakukan dengan menggantikan sebagian bahan penyusun ransum dengan limbah agroindustri, diantaranya dedak padi atau jagung diganti dengan sekam padi atau serbuk gergaji kayu atau kotoran ayam (Yadnya dan Sukmawati, 2006).

Kelemahan pemanfaatan limbah agroindustri yaitu kandungan serat kasar yang tinggi berpengaruh terhadap kecernaan yang rendah. Yadnya (2000) telah mencoba pemberian ransum $12 \%$ serat kasar ternyata daya cerna serat dalam ransum hanya $7,3 \%$ dan setelah disuplementasi dengan Lactobacillus complex dapat meningkatkan kecernaaan serat meningkat menjadi 17,3\%. Jika diperhatikan dari pertambahan bobot badan lebih rendah daripada pemberian ransum kontrol, namun penurunan kandungan serat kasar dari 12\% menjadi 8\% disuplementasi dengan EM-4 ternyata tidak berbeda dengan pemberian ransum kontrol, terbukti nilai FCRnya mendekati sama.

Penggantian 50\% dedak padi dengan sekam padi atau serbuk gergaji kayu yang disuplementasi zat probiotik starbio, ternyata menghasilkan bobot badan akhir pada umur 20 minggu lebih rendah daripada pemberian ransum kontrol (Yadnya dan Sukmawati, 2006). Hal ini mungkin disebabkan sekam padi mengandung nutrisi gizi adalah 12,5\% air, 3,1\% protein, 29,2\%, bahan ekstrak tiada nitrogen (BETN), 35\% serat kasar, 2,7\% lemak, dan $17,5 \%$ abu dengan kecernaan yang rendah (Lubis, 1992). Dengan rendahnya protein yang dapat dimanfaatkan menjadi daging, maka perlu ditambahkan dengan asam amino sehingga dalam asam amino terjadi deaminasi, gugus amino yang dihasilkan akan bereaksi dengan asam keto karboksilat, terbentuklah asam amino yang baru akan dapat meningkatkan protein yang baru. (Wirahadikusumah, 1985). Lebih lanjut dijelaskan, bahwa kekurangan asam amino akan bisa dilakukan dengan transaminasi yang dibarengi dengan deaminasi, sehingga kekurangan asam dan protein bisa diatasi. Salah satu yang bisa digunakan sebagai asam amino perantara yaitu mono sodium glutamat (MSG).

\section{MATERI DAN METODE}

\section{Tempat dan Lama Penelitian}

Penelitian pemanfatan sekam padi terbiofermentasi Lactobacillus complex disuplementasi mono sodium glutamat dilaksanakan di Desa Guwang, Kecamatan Sukawati, Kabupaten Gianyar selama 10 minggu. Penelitian karkas dan kualitas daging dilaksanakan di Laboratorium Teknologi Hasil Ternak, Fakultas Peternakan, Universitas Udayana selama empat minggu.

\section{Itik}

Itik yang dipergunakan adalah itik campbell yang unisex dibeli dari agen poultry shop di Tohpati, Denpasar dengan umur dan bobot badan yang homogen.

Kandang dan Perlengkapannya

Kandang yang dipergunakan sistem postal dari bilah-bilah bambu dengan ukuran kandang: panjang 1,7 m., lebar 1,6 m dan tinggi $2 \mathrm{~m}$. Pada bagian lantai diisi sekam padi setebal $15 \mathrm{~cm}$. Kandang dilengkapi tempat makan dan tempat air minum yang terbuat dari bambu dan terletak di luar, serta lampu untuk penerangan pada waktu malam hari.

\section{Ransum dan Air Minum}

Ransum ysng diberikan disusun berdasarkan perhitungan Scott et al. (1982) yang terdiri atas jagung kuning, dedak padi, bungkil kelapa, tepung ikan, kacang kedelai, mono sodium glutamat (MSG), premix, dan $\mathrm{NaCl}$. Komposisi bahan ransum dan kimia bahan ransum tertera pada Tabel 1 dan 2. Ransum dan air minum diberikan dengan ad libitum. Air minum berasal dari PDAM setempat. 
Tabel 1. Komposisi bahan ransum dalam itik, umur 2-8 minggu

\begin{tabular}{lcccc}
\hline \multirow{2}{*}{ Bahan Ransum (\%) } & \multicolumn{4}{c}{ Perlakuan } \\
\cline { 2 - 5 } & $\mathrm{A}$ & $\mathrm{B}$ & $\mathrm{C}$ & $\mathrm{D}$ \\
\hline Jagung kuning & 55,36 & 55,36 & 56,36 & 56,36 \\
Tepung ikan & 8,12 & 8,12 & 8,12 & 8,12 \\
Dedak padi & 14,14 & 7,04 & 6,04 & 4,04 \\
Bungkil kelapa & 9,31 & 6,31 & 3,31 & 3,31 \\
Kacang kedelai & 11,97 & 11,97 & 11,97 & 11,97 \\
Sekam padi & - & 4,94 & 5,97 & 6,94 \\
Na-Sodium Glutamat & - & 3,36 & 5,94 & 6,34 \\
Premix & 0,50 & 0,40 & 0,36 & 0,40 \\
NaCl & 0,52 & 0,42 & 0,40 & 0,42 \\
Total & 100 & 100 & 100 & 100
\end{tabular}

Tabel 2. Komposisi kimia ransum itik Campdell berumur2-8 minggu

\begin{tabular}{|c|c|c|c|c|c|c|}
\hline \multirow{2}{*}{$\begin{array}{l}\text { Zat-zat } \\
\text { makanan }\end{array}$} & \multirow[b]{2}{*}{ Satuan } & \multicolumn{4}{|c|}{ Perlakuan } & \multirow{2}{*}{$\begin{array}{l}\text { Standard } \\
\text { Scott et al. } \\
\text { (1982) }\end{array}$} \\
\hline & & A & B & C & D & \\
\hline \multicolumn{2}{|c|}{$\begin{array}{l}\text { Energi Metabo-Kkal/kg } \\
\text { lisme }\end{array}$} & 2879,6 & 2856,9 & 2807,5 & 2820,5 & 2800 \\
\hline Protein Kasar & $\%$ & 19,3 & 17,8 & 17,2 & 16,9 & 18 \\
\hline Lemak & $\%$ & 7,5 & 8,12 & 7,9 & 8,6 & $6-9$ \\
\hline Serat kasar & $\%$ & 4,62 & 5,07 & 5,77 & 5,72 & $<5$ \\
\hline Kalsium & $\%$ & 0,27 & 0,26 & 0,26 & 0,25 & 0,60 \\
\hline $\mathrm{P}$ tersedia & $\%$ & 0,39 & 0,32 & 0,30 & 0,30 & 0,60 \\
\hline
\end{tabular}

Keterangan:

A: ransum tanpa sekam, MSG dan EM-4, B: ransum dengan 4,94\% sekam padi, 3,36\% MSG dan EM-4, C: ransum dengan 5,97\% sekam padi, 5,94\% MSG, dan EM-4, D: ransum dengan $6,94 \%$ sekam padi, $6,34 \%$ MSG dan EM-4.

\section{Rancangan Percobaan}

Rancangan percobaan yang digunakan adalah rancangan acak lengkap (RAL) dengan empat perlakuan yaitu ransum kontrol (A), ransum mengandung 4,94\% sekam padi, 3,36\% MSG, dan EM-4, ransum mengandung 5,97\% sekam padi, 5,94\% MSG, dan EM-4 (C), dan ransum mengandung 6,94\% sekam padi, 6,34\% MSG (D). Setiap perlakuan dengan empat ulangan dan setiap ulangan berisi empat ekor itik campbell dengan umur dan bobot badan yang homogen.

\section{Peubah yang diamati meliputi :}

1. Konsumsi ransum adalah ransum yang diberikan dikurangi dengan sisa ransum selama penelitian

2. Bobot potong adalah bobot akhir penelitian sebelum dipotong

3. Bobot karkas adalah bobot potong dikurangi bobot bukan karkas (darah bulu, kepala dan kaki)

4. Persentase karkas adalah bobot karkas dibagi bobot potong dikalikan $100 \%$

5. Komposisi fisik karkas adalah bobot daging, tulang dan kulit, masing-masing dibagi bobot karkas dikalikan $100 \%$

6. Kualitas daging meliputi kadar air dengan metode pemanasan (AOAC, 1979), daya ikat air (WHC) dengan menggunakan metode Connel dan Howgate (Adipta, 1991), derajat keasaman dengan $\mathrm{pH}$ meter digital active model $20 \mathrm{gpH} /$ mv meter

\section{Analisis Stastistika}

Data yang diperoleh ditabulasi, kemudian dinalisis dengan sidik ragam, dan dilanjutkan dengan Uji Duncan (Stell dan Torrie, 1989)

\section{HASIL DAN PEMBAHASAN}

\section{Konsumsi ransum}

Konsumsi ransum untuk itik yang diberikan ransum kontrol adalah $4575 \mathrm{~g} /$ ekor selama enam minggu (Tabel 3). Pemberian ransum yang mengandung $4,94 \%$ sekam padi, 3,36\% MSG dan EM-4 (B), ransum mengandung 5,97\% sekam padi, 5,94\% MSG dan EM-4 (C), dan ransum mengandung 6,94\% sekam padi, 6,36\% MSG dan EM-4 (D) masing-masing mengkosumsi ransum adalah 15,02\%, 15,25\% dan 21,48\% lebih tinggi $(\mathrm{P}<0,05)$ daripada pemberian perlakuan A. Konsumsi ransum pada pemberian perlakuan $\mathrm{B}, \mathrm{C}$, dan $\mathrm{D}$ lebih tinggi $(\mathrm{P}<0,05)$ daripada pemberian perlakuan kontrol (A) (Tabel 3). Pemberian B, C, dan D dapat meningkatkan konsumsi serat kasar yang berpengaruh terhadap kecernaan ransum yang lebih rendah sehingga itik mengkonsumsi lebih banyak agar kebutuhan hidupnya bisa terpenuhi (Anggorodi, 2004).

\section{Karkas}

Bobot potong pada itikA adalah 1172,50 g/ekor (Tabel 3). Pemberian perlakuan $\mathrm{B}$ dan $\mathrm{C}$ dapat meningkatkan bobot potong sebesar $14,75 \%$ dan $7,46 \%(\mathrm{P}<0,05)$, sedangkan pemberian perlakuan $\mathrm{D}$ tidak berpengaruh terhadap bobot potong $(\mathrm{P}>0,05)$ dibandingkan dengan pemberian perlakuan kontrol (A). Hal ini sangat terkait dengan banyaknya serat kasar yang dikonsumsi, ternyata pada perlakuan D mengkonsumsi serat kasar lebih banyak daripada pemberian perlakuan B dan C, sehingga bobot potongnya lebih besar daripada botong pada pemberian ransum A atau D. Karkas sangat ditentukan oleh bobot potong dan bobot bukan karkas (Anggorodi, 2004). Hal ini sesuai dengan pendapat Barhiman (1976), melaporkan bahwa semakin besar bobot potong maka akan disertai dengan bobot karkas yang lebih besar. Pemberian ransum mengandung sekam padi, mono sodium glutamat tidak berpengaruh terhadap karkas, karena persentase karkas sangat dipengaruhi oleh bobot potong dan bobot karkas.

Pemberian perlakuan D dapat meningkatkan produksi daging dan tulang dan dapat menurunkan persentase lemak. Adanya bantuan bakeri Lactobacillus complex (Higa dan Wididana,1993), sekam padi sebagai sumber serat difermentasi oleh bakteri Lactobacillus 
Tabel 3. Respon pemberian mono sodium glutamat dalam ransum sekam padi yang berbeda disuplementasi EM-4 terhadap karkas pada itik campbell

\begin{tabular}{|c|c|c|c|c|}
\hline \multirow{2}{*}{ Peubah yang diamati } & \multicolumn{4}{|c|}{ Perlakuan ${ }^{1)}$} \\
\hline & A & B & C & D \\
\hline $\begin{array}{l}\text { Konsumsi ransum } \\
\text { (g/ekor) }\end{array}$ & $4575,0 b^{21}$ & $5262,5 a$ & $5273,0 a$ & $5555,8 a$ \\
\hline $\begin{array}{l}\text { Konsumsi Protein ransum } \\
\text { (g/ekor) }\end{array}$ & $883,45 a$ & $936,72 a$ & $906,95 a$ & $1030,13 a$ \\
\hline $\begin{array}{l}\text { Konsumsi serat ransum } \\
\text { (g/ekor) }\end{array}$ & $211,48 d$ & $266,80 c$ & $298,48 b$ & $317,91 a$ \\
\hline Bobot potong (g/ekor) & $1172,5 c$ & $1345,0 a$ & $1260,0 b$ & $1170,0 c$ \\
\hline Bobot karkas (g/ekor) & $770,0 c$ & $910,0 a$ & $850,0 b$ & $785,0 \mathrm{c}$ \\
\hline Persentase karkas (\%) & $65,67 a$ & $67,65 a$ & $67,46 a$ & $67,09 a$ \\
\hline Daging (\%) & $46,75 d$ & $48,33 b$ & $47,25 c$ & $49,68 a$ \\
\hline Tulang (\%) & $26,29 d$ & $27,14 c$ & $29,93 a$ & $28,87 b$ \\
\hline Lemak termasuk kulit (\%) & $26,96 a$ & $24,53 b$ & $22,82 c$ & $21,95 c$ \\
\hline
\end{tabular}

Keterangan:

A: ransum tanpa sekam, MSG dan EM-4, B: ransum dengan 4,94\% sekam padi, 3,36\% MSG dan EM-4, C: ransum dengan 5,97\% sekam padi, 5,94\% MSG, dan EM-4, D: ransum dengan $6,94 \%$ sekam padi, $6,34 \%$ MSG dan EM-4

Nilai dengan huruf yang berbeda dalam baris yang sama berarti berbeda nata $(P>0,05$

complex. Candra et al. (2012) melaporkan fermentasi sekam padi dapat menghasilkan peningkatkan nutrisi sekam padi, asam amino meningkat, disertai dengan penurunan kandungan serat, serta peningkatan nutrisi lainnya. Adanya MSG akan dapat meningkatkan asam amino untuk meningkatkan produksi daging yang dihasilkan. Hasil penelitian ini sesuai yang diperoleh Belawa (2001) yang melaporkan pemberian zat probiotik dalam ransum yang mengandung serat berbeda dapat meningkatkan daging dan menurunkan lemak karkas.

\section{Kualitas Daging}

Kualitas daging dengan metode obyektif ditentukan oleh $\mathrm{pH}$, kadar air, daya ikat air, dan susut masak (USDA, 1977).

Tabel 4. Kajian pemanfaatan monosodiumglutamat (MSG) dalam ransum sekam padi yang disuplementasi larutan Lactobacillus complex terhadap kualitasdaging itik campbell

\begin{tabular}{ccccc}
\hline \multirow{3}{*}{ Peubah } & \multicolumn{4}{c}{ Perlakuan $^{1)}$} \\
\cline { 2 - 4 } SEM $^{3}$ ) \\
\cline { 2 - 4 }
\end{tabular}

\begin{tabular}{|c|c|c|c|c|c|}
\hline \multicolumn{6}{|l|}{$\begin{array}{l}\text { Penilaian secara } \\
\text { obyektif }\end{array}$} \\
\hline $\mathrm{pH}$ & $5,89 a^{2)}$ & $5,91 a$ & $5,89 a$ & $5,85 a$ & 0,01 \\
\hline Daya ikat Air (\%) & $57,03 d$ & $62,86 a$ & $58,61 b$ & $57,66 c$ & 0,12 \\
\hline Kadar Air (\%) & $73,24 a$ & $73,58 a$ & $73,76 a$ & $73,88 a$ & 0,56 \\
\hline \multicolumn{6}{|l|}{$\begin{array}{l}\text { Penilaian secara } \\
\text { subyektif }\end{array}$} \\
\hline Aroma & $6,2 c$ & $6,9 a$ & $6,4 b$ & $6,5 b$ & 0,06 \\
\hline Cita rasa & $6,9 b$ & $7,6 a$ & $6,8 b$ & $6,2 b$ & 0,05 \\
\hline Tekstur & $6,5 b$ & $7,65 a$ & $6,8 a$ & $6,8 a$ & 0,07 \\
\hline Nilai keseluruhan & $7,2 c$ & $7,8 a$ & $7,5 b$ & $7,5 b$ & 0,07 \\
\hline
\end{tabular}

Keterangan:

A: ransum tanpa sekam, MSG dan EM-4, B: ransum dengan 4,94\% sekam padi, 3,36\% MSG dan EM-4, C: ransum dengan 5,97\% sekam padi, 5,94\% MSG, dan EM-4, D: ransum dengan $6,94 \%$ sekam padi, 6,34\% MSG dan EM-4

Nilai dengan huruf yang berbeda dalam baris yang sama berarti berbeda nata $(P>0,05)$ SEM : Standard Error of the Treatment Means

\section{Penilaian Secara Objektif}

Kualitas daging secara objektif meliputi $\mathrm{pH}$, kadar air dan daya ikat air pada daging itik A adalah 5,89, 73,24\% dan 57,03\% (Tabel 4). Kualitas daging dengn metode objektif diperoleh $\mathrm{pH}$, dan kadar air daging pada semua perlakuan tidak berpengaruh (Tabel 4), sedangkan pada daya ikat air ada peningkatan pada ransum yang mengandung sekam padi, MSG dan pemberian EM-4 melalui air minum. Pemberian ransum yang berserat fesesnya agak basah, sehingga air yang diminum dengan yang dikeluarkan melalui feses seimbang, dan kadar air pada daging medekati sama (Bidura et al., 1996). Keadaan air yang sama memberikan gambaran jumlah muatan positif dan negatif berimbang, sehingga ion $\mathrm{H}^{+}$yang dihasilkan dengan yang dimanfaatkan dengan yang dihasilkan mendekati sama. Pada pemberian perlakuan B, C, D dapat meningkatkan daya ikat air (DIA) $(\mathrm{P}<0,05)$ daripada pemberian perlakuan kontrol (A). Hal ini sangat terkait dengan konsumsi protein dan kandungan protein dalam darah yang lebih tinggi, akan memberikan peluang sekelompok protein yang hidrofilik mengikat molekul-molekul air melalui ikatan hidrogen yang satu dengan yang lainnya berikatan dengan ion negatif dan gugus karboksilat yang terdapat pada asam-asam amino yang terdapat dalam protein daging atau kulit (Purnomo dan Padaga, 1989). Hal ini yang menyebabkan perlakuan $\mathrm{B}, \mathrm{C}$, dan D lebih tinggi daripada perlakuan A.

Penelitian organoleptik pada kualitas daging pada pemberian perlakuan $\mathrm{B}$ menghsilkan penilaian yang paling disukai. Hal ini disebabkan daya ikat air (DIA) pada daging itik perlakuan $\mathrm{B}$ lebih tinggi sehingga substansi atsiri (volatil) yang terdapat dalam daging lebih banyak. Menurut Soeparno (2005), aroma daging masak ditentukan oleh pembebasan atsri volatil yang terdapat dalam daging. Daya ikat air yang lebih besar akan berpengaruh kepada masak susut daging yang lebih rendah, sehingga substansia non protein yang larut dalam air dan lemak merupakan prekursor daripada cita rasa daging (Horstein, dalam Soeparno, 2004). Adanya daya ikat air yang lebih tinggi mentebabkan lemak dalam jaringan tubuh ternak mampu melarutkan jaringan kolagen sehingga tekstur daging lebih lembut dan empuk (Soeparno, 2005).

\section{SIMPULAN}

Dapat disimpulkan bahwa pemberian ransum dengan 3,36\% sekam padi, 3,36\% MSG dan larutan Effective Microorganisms-4 (EM-4) melalui air minum dapat memperbaiki karkas dan kualitas daging itik campbell. 


\section{UCAPAN TERIMA KASIH}

Pada kesempatan ini penulis mengucapkan terima kasih kepada Rektor Universitas Udayana atas dana yang diberikan melalui dana Penelitia Dosen Muda, sehingga penelitian dan penyusunan tulisan ilmiah ini dapat terlaksana. Ucapan terimakasih penulis juga sampaikan kepada Agus Yovi, SPt., atas bantuannya dalam analisis kualitas daging.

\section{DAFTAR PUSTAKA}

Adipta, M. P. 1991.Pengaruh Penambahan Enzim Papain Pada Pengolahan Betutu Itik Afkir. Skripsi S1. Program Studi Teknologi Pertanian Unud.

AOAC. 1979. Official Methode of the Association of Official Analitical Chemistis (AOAC), $12^{\text {th }}$, Washington, DC.

Anggorodi, R. 2004. Ilmu Makanan Ternak Umum, PT.Gramedia, Jakarta.

Bidura, I G. N. G. 1998. Pengaruh aras serat kasar ransum terhadap produksi telur ayam Lohmann Brown , Majalah ilmiah Peternakan, Fapet, Unud. 2 (2) : 23-27.

Belawa, Y. T. G. 2001. Pengaruh Pemberian Tingkat Serat yang disuplementasi dengan Probiotik Starbio terhadap Konversi Ransum, kadar protein, asam urat dan kolesterol darah dan komposisi karkas Itik Bali, Umur 10 Minggu. Proc. SeminarNasional, IP2TP, Denpasar.

Belawa Yadnya. T. G. dan N.M.Suci Sukmawati. 2006.
Pengaruh penggantian dedak padi dengan sekam padi atau serbuk gergaji kayuyang disuplementasi probiotik terhadap efisiensi penggunaan ransum dan kadar asam urat darah itik Bali. MIP.Volume 9, Nomor 2, Tahun 2006. ISSN : 0853-8999. Fakultas Peternakan.Universitas Udayana, Denpasar.

Chandra, T., V. G. Kereh., I M. Untu dan B. W. Rambet. 2012. Pengayaan NNSP berbasis Bioteknologi EM-4 sebagai pakan organik Fapet, Universitas Sam Ratulangi, Manado, Jurnal Zootek. Vol. 32. Nomor 5 , p. $158-171$.

Higa, T dan I G. N. Wididana. 1993. Effective Microorganisms-4 (EM-4) Seri Pertanian Akrab Lingkungan, Jakarta.

Lubis, D. A. 1992. Ilmu Makanan Ternak. PT. Pembangunan, Jakarta.

Purnomo, H. dan M.C. Plaga. 1989. Ilmu Daging. Penerbit Universitas Brawijaya, Malang

Scott, M. L., M. C. Nesheim., and R. J. Young. 1982. The Nutrient of the Chickens. 3rd Ed.M.L.Scott.Assoc. , Ithaca., New York.

Steel , R. G. D., and J. H. Torrie. 1989. Principle and Procedures of Statistics.McGraw-Hill.

Soeparno. 2005. Ilmu dan Teknologi D.Gadjah Mada Univrtsity Press, Cetakan Keempat, Yogyakarta.

USDA, 1977. Poultry Grading Manual. US. Goverment Publishing Office Washington DC.

Wirahadikusumah, M. 1985. Biokimia : Metabolisme energi, karbohidrat dan lipid. Penerbit: ITB, Bandung. 